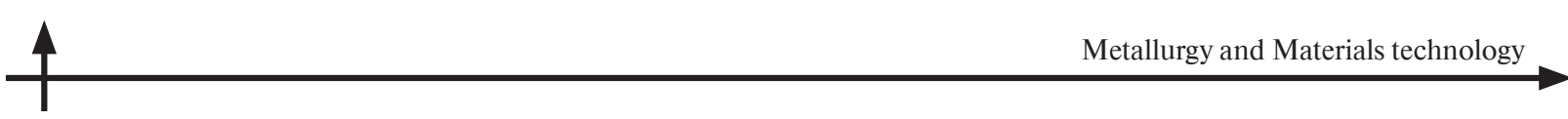

\title{
INFLUENCE OF STRUCTURE AND PHASE COMPOSITION OF THE MATERIAL OF STEAM TURBINE BLADES FROM TITANIUM ALLOYS ON THEIR RESISTANCE TO EROSIVE DESTRUCTION
}

\author{
Н.А. Крылов, М.А. Скотникова, Г.В. Цветкова, Г.В. Иванова
}

\section{ВЛИЯНИЕ СТРУКТУРЫ И ФАЗОВОГО СОСТАВА МАТЕРИАЛА ЛОПАТОК ПАРОВЫХ ТУРБИН ИЗ ТИТАНОВЫХ СПЛАВОВ НА ИХ УСТОЙЧИВОСТЬ К ЭРОЗИОННОМУ РАЗРУШЕНИЮ}

\begin{abstract}
Titanium alloys keep a leading position in manufacturing steam turbine blades. The unique combination of high specific strength and fracture toughness, corrosion resistance, polymorphism, a tendency to phase transformations and high resistance to shock loading determined their wide application in power engineering. However, power engineering is still facing a problem of erosion damage of steam turbine blades as a result of a drop impact of vapor particles at speeds of $150 \ldots 600 \mathrm{~m} / \mathrm{s}$. The complication in solving this problem is that it is difficult to establish a link between wear and structural-phase composition of the surface of turbine blades. In this paper, using optical metallography, electron microscopy, ray analysis and X-ray microspectral analysis, we developed a method for studying structural and phase transformations in the material of steam turbine blades of titanium alloy VT6 after technological treatments in different modes. An attempt was made to establish a link between resistance to erosion destruction and structural and phase composition of titanium alloys.
\end{abstract}

STEAM TURBINE; STRUCTURAL AND PHASE TRANSFORMATIONS; OPTICAL METALLOGRAPHY; ELECTRON MICROSCOPY; X-RAY MICROSPECTRAL ANALYSIS.

\begin{abstract}
Титановые сплавы сохраняют лидирующее положение в производстве лопаток паровых турбин. Уникальное сочетание высокой удельной прочности и вязкости разрушения, коррозионной стойкости, полиморфизм, склонность к фазовым превращениям и высокая устойчивость к ударной нагрузке определили их широкое применение в энергетике. Тем не менее в энергетическом машиностроении до сих пор существует проблема эрозионного повреждения лопаток паровых турбин в результате каплеударного воздействия частиц пара со скоростями 150-600 м / с. Сложность решения этой проблемы заключается в том, что трудно установить связь между износом и структурно-фазовым составом поверхности лопаток турбин. В данной работе с использованием оптической металлографии, электронной микроскопии, рентгеноструктурного анализа и рентгеновского микроспектрального анализа разработан метод исследования для изучения структурных и фазовых превращений в материале паровых лопаток турбин из титанового сплава ВТ6, после технологической обработки на различных режимах. Предпринята попытка установить связь между устойчивостью к эрозионному разрушению и структурно-фазовым составом титановых сплавов.
\end{abstract}

ПАРОВЫЕ ТУРБИНЫ; СТРУКТУРНЫЕ И ФАЗОВЫЕ ПРЕВРАЩЕНИЯ; ОПТИЧЕСКАЯ МЕТАЛЛОГРАФИЯ; ЭЛЕКТРОННАЯ МИКРОСКОПИЯ; МИКРО-РЕНТГЕНОСПЕКТРАЛЬНЫЙ АНАЛИЗ.

\section{Introduction}

Titanium alloys keep a leading position in the creation of steam turbine blades. The unique combination of high specific strength and fracture toughness, corrosion resistance, polymorphism, a tendency to phase transformations and high resistance to shock loading defined their wide application in power engineering (for example see fig. $1, a, b)$ ) [1, 2]. 

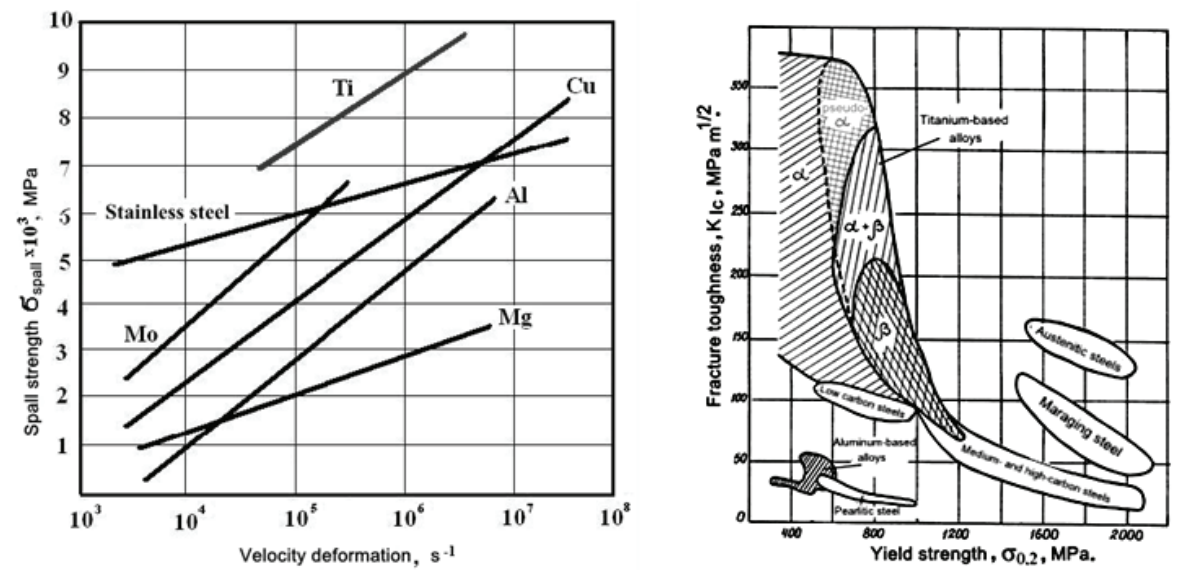

Fig. 1. Dependence of spall strength from velocity deformation for different metals $(a)$;

dependence of fracture toughness from yield strength for titanium alloys $(b)$

However, the power engineering still has a problem of erosion damage of steam turbine blades as a result of a drop impact of vapor particles at a speed of $150-600 \mathrm{~m} / \mathrm{s}$. The difficulty of solving the problem is that difficult to establish a link between wear and structural-phase composition of the surface of turbine blades (the typical example of erosion destruction of steam turbine blades is shown in fig. 2).

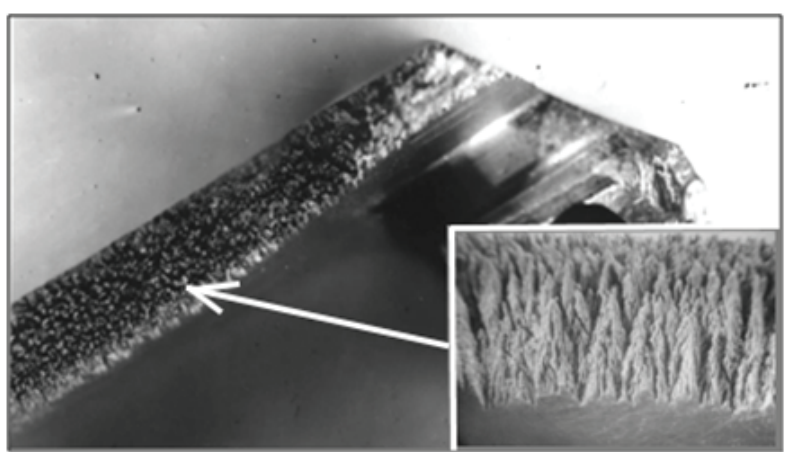

Fig. 2. Example of erosion destruction of steam turbine blades

Two-phase titanium alloys found wide application in turbine construction due to opinion [3], that the greatest resistance to effect of exposure steam drops should be two-phase alloys with low internal stresses and high plastic properties, during which time of stress there exist phase transformations strengthening the subject material.

At effect of exposure steam drops, field sizes of a stressing are commensurable with sizes of structural components, and redistribution of internal stresses between them is impossible. The role of individual durability, intensity, a chemical composition and phase transformations in separate structural compo- nents therefore increases. To solve this problem it is necessary find the relation between the wear and structural-phase state of the surface and axial layers of blades material.

\section{The object of research}

The object of research has been samples of steam turbine blades of the two-phase titanium alloy VT6 (Ti-6Al-4V) average strength after deformation in $b$ area and final deformed by stamping in areas $\alpha+\beta$ next to the reduced temperatures $T_{50}$ and $T_{70}$, corresponding to the first and second technology. The temperature of final transition of an alloy in b- region $\left(T_{\mathrm{pt}}\right)$ was made $1015{ }^{\circ} \mathrm{C}$.

As follows from earlier carried out works [4-8], on the basis of complex research of mechanisms of formation and decomposition nonequilibrium $\beta(\alpha)$ and $\alpha(\beta)$ - phases, redistribution between them of alloying elements, physical and mechanical properties of the deformed titanium alloys of a different alloying, and also the established laws, the generalized kinetic diagram, fig. 3, has been constructed. Thus we took into account not only a temperature of heating absolute $(T)$, but also produced the identical contents of high-temperature $\beta$-phases $\left(T_{\beta}\right)$. We established, that the more nonequilibrum $\beta(\alpha)$ - and $\alpha(\beta)$ solid solutions contained the same alloying elements; their polystage decomposition occurred at lower temperatures, and for greater time. It is shown, that titanium blanks possess high technological properties in a temperature-time interval two-phase $(\alpha+\beta)$ - region at temperatures identical $(50 \%)$ contents high-temperature $\alpha$ - and $\beta$ - phases $\left(T_{50}\right)$ and near to a temperature of transition in single-phase $\beta$ - region $\left(T_{75}\right)$. 


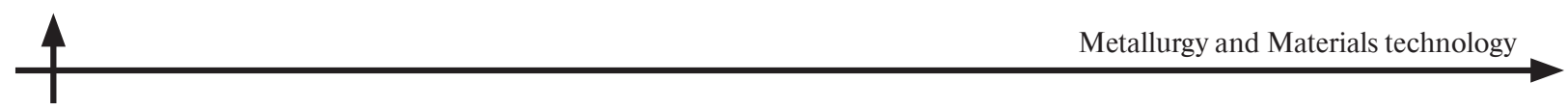

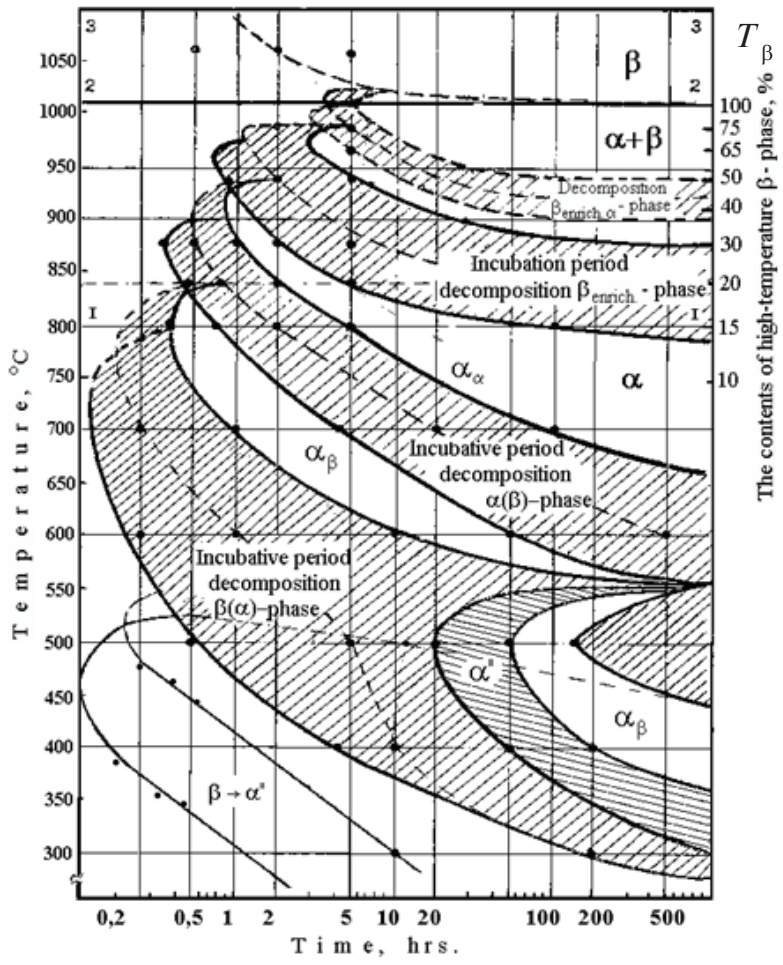

Fig. 3. Generalized kinetic diagram of structure and phase transformation in titanium alloys

The product possesses material with high operational properties after an isothermal exposure near to temperature $T_{15}$. In these cases $\alpha$ - and $\beta$ - phase components appear enriched, the as $\alpha$ - and $\beta$ - stabilizing alloying elements, in these processes of a polygonization that causes increase of plasticity characteristics and allows crack origin of alloys to develop.

Thus, construction of serial curves of increase of the contents high-temperature $\beta$ - phases depending on a temperature of heating (a method of hardening), will allow us to estimate the resulted temperatures of heating and to develop the scientificallygrounded modes of technological treatment of titanium blanks [6].

\section{Structure and the Phase Composition}

Both stamping technology provides a bimodal structure $\alpha$-phase globular $\left(\alpha_{1}\right)$ and platelet-shaped $\left(\alpha_{\text {II }}\right)$, divided by layers of $\beta_{\text {II }}$ - phases (fig. $\left.4, a, b\right)$. Electron microscope photos (fig. $4, c, d$ ) shows that the boundaries of phase components $\left(\alpha_{\mathrm{I}}, \alpha_{\mathrm{II}}, \beta_{\mathrm{II}}\right)$ for the first technology much better relaxation, due to customizations of dislocation. The second technology is seen less of number curved extinction contours, indicate the presence of internal stresses.
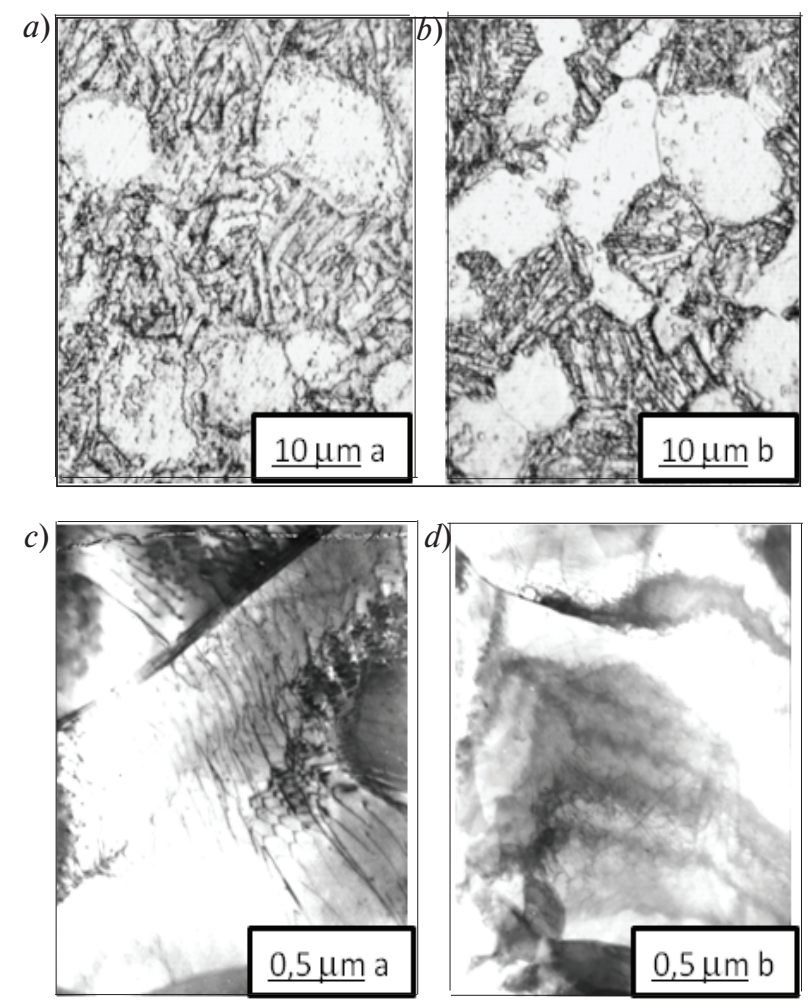

Fig. 4. The microstructure after stamping on the first ( $a$ ) and second (b) technologies; the electron microscope structure after stamping on the first $(c)$ and second $(d)$ to technologies

As seen from the table 1 , width plate of $\alpha_{\text {II }}$ - phase by the first technology in 3 times and interlayers of $\beta_{\text {II }}$-phase in 8 times greater than by the second technology. This evidence different temperatures and cooling rates. By the first technology, at low-temperature is formed structure similar to the Widmanstatten. Such structure, in a number of sources, has a higher fatigue strength than the martensite-like by the second technology [9]. In materials of both blades with bimodal structure, the size lamellar $\left(\beta_{\mathrm{II}}+\alpha_{\mathrm{II}}\right)$ - a component was more size globular $\alpha_{I}$ - phases.

\section{Distribution of Alloying Elements}

The research results obtained by X-ray microspectral analysis of the contents of alloying elements (aluminum, vanadium, titanium, iron) in separate phase components shows in table 2. 
Table 1

The particles size of phase components of metal blades, fabricated on two technologies

\begin{tabular}{|c|c|c|}
\hline Phase components & $\begin{array}{c}\text { Size of particles of phases after the first } \\
\text { technology, } \mu \mathrm{m}\end{array}$ & $\begin{array}{c}\text { Size of particles of phases after the } \\
\text { second technology, } \mu \mathrm{m}\end{array}$ \\
\hline$\alpha_{\mathrm{I}}$ & 15 & 12 \\
$\alpha_{\mathrm{II}}$ & 2,2 & 0,7 \\
$\beta_{\mathrm{II}}$ & 0,8 & 0,1 \\
$\alpha_{\mathrm{II}}+\beta_{\mathrm{II}}$ & 22 & 18 \\
\hline
\end{tabular}

Table 2

The contents of alloying elements in phase components of metal blades, fabricated on two technologies

\begin{tabular}{|c|c|c|c|c|}
\hline \multirow{2}{*}{ Phase components } & \multicolumn{2}{|c|}{$\begin{array}{c}\text { Concentration after the first technology, } \\
\text { weight } \%\end{array}$} & $\begin{array}{c}\text { Concentration after the second technology, } \\
\text { weight } \%\end{array}$ \\
\cline { 2 - 5 } & $\mathrm{Al}$ & $\mathrm{V}$ & $\mathrm{Al}$ & $\mathrm{V}$ \\
\hline$\alpha_{\mathrm{I}}$ & 7,30 & 1,35 & 6,97 & 2,04 \\
$\alpha_{\mathrm{II}}$ & 6,01 & 3,60 & 5,68 & 4,21 \\
$\beta_{\mathrm{II}}$ & 4,14 & 9,64 & 4,61 & 8,28 \\
\hline
\end{tabular}

As seen from the table for both technologies, the secondary plates of $\alpha_{I I}$ - phase have a chemical composition that is comparable to the average composition of the alloy Ti-6AL-4V. The globular primary $\alpha_{1}$ - phase, compared with the plate $\alpha_{\text {II }}$ - phase contains less than $2,2 \%$ vanadium and more than $1,3 \%$ aluminum. Thin layers of secondary $\beta_{\mathrm{I}}$ - phase have been enriched by vanadium ( $\beta$-stabilizer). In the material by the first technology $\beta_{\text {II }}$ - phase contains vanadium more at $1,3 \%$ and aluminum less at $0,5 \%$, than the second technology.

Such distribution alloying elements provides relative softness of layers $\beta_{\mathrm{II}}$ - phase and higher perfor- mance as compared with the second technology, in which inverse ratio of alloying elements [10]. On the contrary, globalizes primary $\alpha_{\mathrm{I}}$ - phases in blades material fabricated on the first technology, in comparison with the second, contained a vanadium less on $0,6 \%$ and aluminum more on $1,3 \%$ (weight).

The fig. 5 shows a typical distribution of the alloying elements with step 0,5 microns. It is seen, that is most non-uniform in a material the vanadium is distributed, being focused in $\beta_{\mathrm{II}}$ - phase. Its concentration changes from 1 up to $20 \%$. Aluminum is distributed more similarly, its concentration changes from 3 up to $7 \%$.

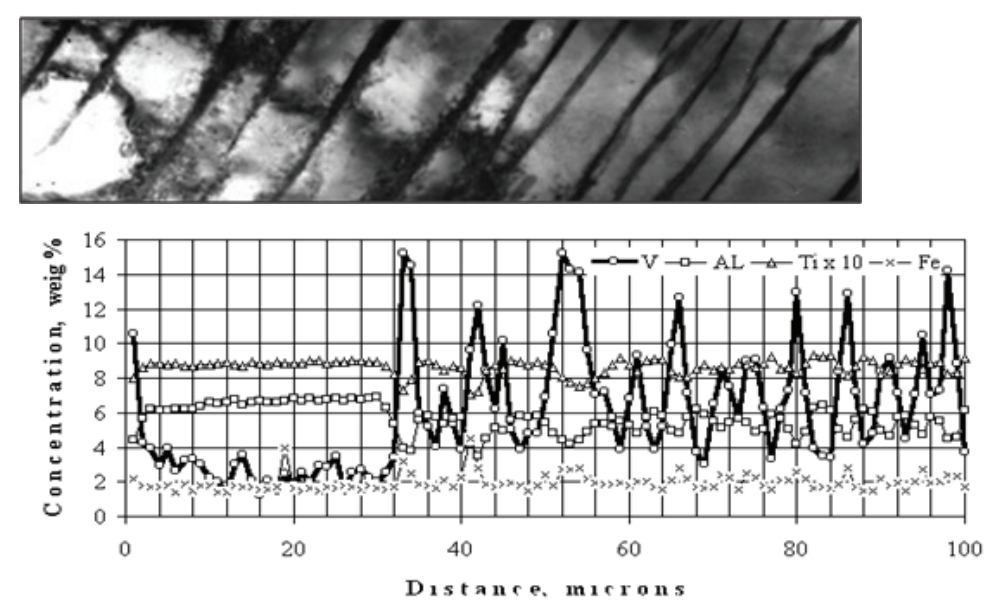

Fig. 5. The microstructure and distribution of alloying elements in structural components of material blades from alloy VT6. 


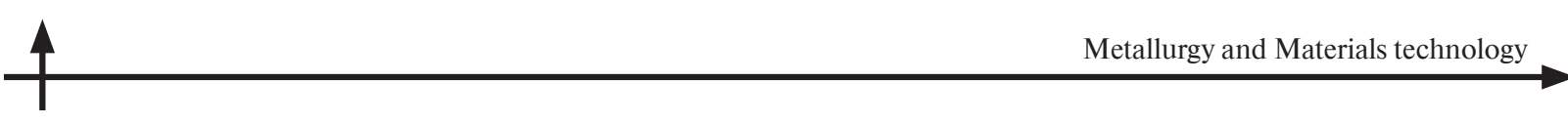

\section{Microhardness of phase components}

In Table 3 are shown the data of statistical treatment of results of measurements microhardness of separate phase components. It is seen that the microhardness of the material by the second technology is higher than the first, which confirms the presence of internal stresses. It is necessary noted that the first technology makes less the difference between the hardness of globular and lamellar structure.

The blades material fabricated on both technologies had a bimodal structure. Probably, the strength balance $\alpha_{\mathrm{I}}$ - and $\left(\alpha_{\mathrm{II}}+\beta_{\mathrm{I}}\right)$ - structural fashions can guarantee high serviceability of a material under loa-ding. Apparently from table 3 , in blades materials fabricated on the first technology, in comparison with the second, the smaller difference in hardness between globular and lamellar structures, which made 551 and $644 \mathrm{MPa}$, accordingly has been achieved.
On fig. 6 correlation dependences of results of measurements of microhardness on a chemical compound of separate phases $\left(\alpha_{\mathrm{I}}, \alpha_{\mathrm{II}}, \beta_{\mathrm{II}}\right)$ in a condition of delivery and in a martensite phase after hardenings from different temperatures are submitted. It is seen that the microhardness of plates $\alpha_{\mathrm{II}}$-phase and the globules of $\alpha_{I}$-phase increases with them a and $b$ stabilizing elements. It should be noted that the microhardness increases with growth of a-stabilizer, probably due to the formation $\alpha^{\mathrm{I}}$ - martensite and decreases with increasing amount of $\beta$ stabilizing elements, leading to the formation $\alpha^{\mathrm{II}}$ - martensite. This agrees with what was seen earlier in the material by the first technology in comparison with the second technology is formed $\beta$-phase with a large content of $\beta$-stabilizing elements. This agrees with the figure, such a distribution of vanadium, gives less microhardness and greater softness of layers $\beta_{\mathrm{II}^{-}}$ phase.

Table 3

\section{Microhardness of phase components of blades metal fabricated on two technologies}

\begin{tabular}{|c|c|c|}
\hline Phase components & $\begin{array}{c}\text { Microhardness of particles of phases } \\
\text { after the first technology, MPa }\end{array}$ & $\begin{array}{c}\text { Microhardness of particles of phases } \\
\text { after the second technology, MPa }\end{array}$ \\
\hline$\alpha_{\mathrm{I}}$ & 3550 & 3664 \\
$\alpha_{\mathrm{II}}$ & 3830 & 4091 \\
$\beta_{\mathrm{II}}$ & 2584 & 3000 \\
$\alpha_{\mathrm{II}}+\beta_{\mathrm{II}}$ & 2999 & 3020 \\
\hline
\end{tabular}

Concentration, weig $\%$

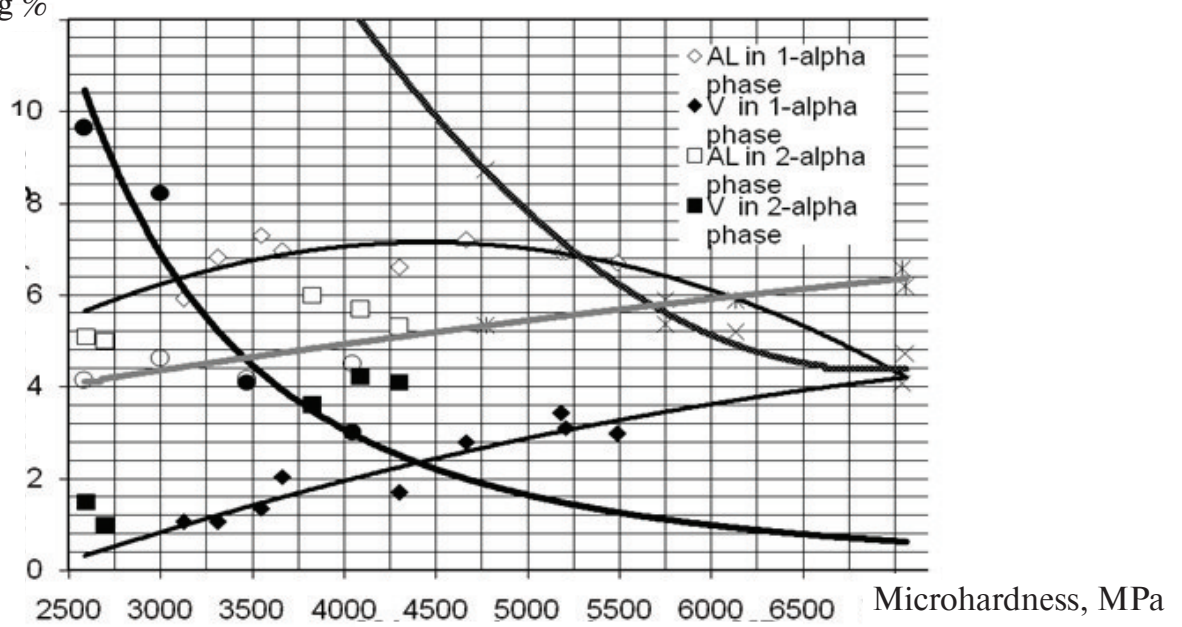

Fig. 6. Dependence of results of a rating of microhardness on a chemical compound of separate phase components $\left(\alpha_{\mathrm{I}}, \alpha_{\mathrm{II}}, \beta_{\mathrm{II}}\right.$, martensite) alloy VT6 


\section{Conclusion}

As results of research have shown, blades materials of steam turbines from alloy VT6 fabricated by final stamping under two technological circuits had bimodal structure, in which the share lamellar $\left(\alpha_{\mathrm{II}}+\beta_{\mathrm{II}}\right)$ structures $(50-70 \%)$ prevailed of a share globular $a_{\mathrm{I}}$ - structures (30-50\%). The blades material fabricated on the first technology, in comparison with the second, possessed wider layers "soft" $\beta_{\mathrm{II}}$ - the phases, enriched same it b-stabilizers. At the same time, this material contained higher concentration of aluminum in primary globalizes $\alpha_{I^{-}}$phases, that pro-vided strength balance (close microhardness) structural components.

It is known, that at cyclic loadings in regular intervals distributed soft faltering layers $\beta_{\mathrm{II}}$ - phases, transiting on the contour of rather solid secondary $\alpha_{I I}{ }^{-}$phases and of strength balance globalizes $\alpha_{\mathrm{I}}$-phases, complicating premature localization of plastic deformation and origin of a crack in separate phases. And at the stage of distribution, the crack is more difficult to increase the length in $\left(\alpha_{\mathrm{II}}+\alpha_{\mathrm{II}}\right)$ lamellar structure as it is always braked by soft layers of $b_{\text {II }}$ - phase and is compelled to change the trajectory, bending around globalized particles $\mathrm{a}_{\mathrm{I}}$ - phases. Thus operational properties of product material increase [9-11].

Feature of effect of exposure steam drops loadings is not only recurrence and cyclicity of the enclosed stress, but also its dynamism. Through of short duration of influence, internal stresses have insufficient time to be redistributed, there is localization of the big loadings in small microvolumes, in separate structural and phase components of material. The suc- cessful combination of structure, chemical compound and properties, abilities to resist the microshock influence of these components, determines durability of products.

Researched alloy VT6 concerning martensite class, in stable condition contains $10-18 \% \beta$ - phases, which at sharp cooling turns in $\alpha^{\mathrm{I}}$ - or $\alpha^{\mathrm{II}}$ - martensite. However, $\beta \rightarrow \alpha^{\mathrm{II}}$ - transformation can take place and at room temperature. It is known, that plastic deformation accelerates decomposition enriched b- stabilizers of b- solid solution with education $\alpha^{\text {II }}$ - phases, as a result of a high level of internal stresses [12]. The subsequent ageing at temperatures $450-500{ }^{\circ} \mathrm{C}$, results in its decomposition and education $\alpha^{I}+(\beta)$ - phases [13]. Presence of phase transformation $\alpha^{\mathrm{II}} \rightarrow \alpha^{\mathrm{I}}+(\beta)$ results in significant strengthening of an alloy.

It is possible to believe, that in result of effect blows by pair, in soft enriched of vanadium, wide, regular intervals distributed $\beta$ - layers there is an accumulation of defects of crystal structure and internal stresses. Transition deformed $\beta$ - phases in a nonequilibrum condition, causes phase $\beta \rightarrow \alpha^{\mathrm{II}}-$ transformation, accompanying with local frictional [14], and as consequence, - the subsequent ageing strengthening of microvolumes of alloy in result $\alpha^{\mathrm{II}}$ $\rightarrow \alpha^{\mathrm{I}}+(\beta)-$ transformations. According to generalized kinetic diagram shown in fig. 3 , the more layers of $\beta$ - phase contain quantity isomorphic $\beta$ - stabilizing elements, those at lower temperatures and for a longer time will be $\beta \rightarrow \alpha^{\text {II }}$ - takes transformation (more completely). Thus, the most important factor is strengthening of borders between solid particles of $\alpha$ - phases which will be increase terms of operation of a finished product, due to increase the resistance to steam drop impact.

\section{REFERENCES}

1. Fedotov S.G., Konstantinov K.M. Novyy konstruktsionnyy material - Titan: Monografiya. M.: Mashinostroyeniye, 1987. 220 s. (rus.)

2. Kanel G.I., Razorenov S.V., Utkin A.V. Udarnovolnovyye yavleniya $\mathrm{v}$ kondensirovannykh sredakh. M.: «Yanus-K», 1999. 408 s. (rus.)

3. Deych M.Ye., Filippov G.A. Dvukhfaznyye techeniya $v$ elementakh teploenergeticheskogo oborudovaniya: Monografiya. M.: Energoatomizdat, 1987. 328 s. (rus.)

4. Skotnikova M.A., Parshin A.M. Diagramma raspada i rezhim termicheskoy obrabotki dvukhfaznykh splavov titana. Metallovedeniye i termicheskaya obrabotka metallov. 1997. № 7. S. 31-37. (rus.)

5. Skotnikova M.A., Lanina A.A. Krylov N.A., Ivanov Ye.K. Strukturno-fazovyye prevrashcheniya v poverkhnostnom sloye lopatki parovoy turbiny pri kapleudarnoy erozii. Problemy resursa $i$ bezopasnoy ekspluatatsii materialov. SPb: Izd-vo SPBGUNiPT, 2007. S. 102-107.

6. Skotnikova M.A., Ushkov S.S. Razrabotka nauchnogo printsip vybora okonchatelnoy termicheskoy obrabotki dvukhfaznykh goryachedeformirovannykh polufabrikatov iz splavov titana. Progressivnyye materialy i tekhnologii. / TsNII KM Prometey. 1999. Vyp. 3. S. 91-98. (rus.) 
7. Skotnikova M.A., Chizhik T.A., Tsybulina I.N. Lanina A.A., Krylov N.A.. Ispolzovaniye titanovykh splavov v kachestve materiala lopatok parovykh turbin.Voprosy materialovedeniya. 2007. № 3 (51) S. 61-70. (rus.)

8. Skotnikova M.A., Lanina A.A. Krylov N.A. Khomchenko Ye.V. Osobennosti stroyeniya materiala lopatok parovykh turbin iz titanovogo splava VT6. Sbornik trudov: Problemy materialovedeniya pri proyektirovanii, izgotovlenii i ekspluatatsii oborudovaniya AES. SPb: Izd-vo FGUP TsNII KM "Prometey", 2010. S. 231-238. (rus.)

9. Park Js., Margolin H. Role $\alpha$ - and $\beta$-phases in distribution of fatique crack to alloys Ti-Mn. Metallurgical Transaction. 1984. Vol. 15A. № 1. P. 155-169.

10. Holl I., Khammond K. Distribution of alloing elements between the phases Titanium alloys during ther- mo-mechanical processing. Proceedings Conference Titanium-77. Moscow, Russia, 1977. Vol. 1. P. 351.

11. Skotnikova M.A., Chizhik T.A., Lisyanskiy A.S., Simin O.N., Tsybulina I.N., Lanina A.A. Issledovaniye rabochikh lopatok turbin bolshoy moshchnosti s uchetom strukturno-fazovykh prevrashcheniy v metalle shtampovok iz titanovogo splava VT6. Metalloobrabotka. 2009. № 6(54). S. 12-21. (rus.)

12. Gridnev V.N., Ivasishin O.M., Oshkaderov S.P. Fizicheskiye osnovy skorostnogo termouprochneniya titanovykh splavov. Kiyev: Naukova dumka, 1986. 256 s. (rus.)

13. Yermolov M.I., Solonina O.P.. Rentgenostrukturnoye issledovaniye fazovykh prevrashcheniy pri termoobrabotke titanovogo splava VT3-1. Fizika metallov $i$ metallovedeniye. 1967. T. 23. № 1. S. 63-69.

\section{СПИСОК ЛИТЕРАТУРЫ}

1. Федотов С.Г., Константинов К.М. Новый конструкционный материал - Титан: Монография. М.: Машиностроение, 1987. - 220 с.

2. Канель Г.И., Разоренов С.В., Уткин А.В. Ударно-волновые явления в конденсированных средах М.: «Янус-К», 1999. 408 с.

3. Дейч М.Е., Филиппов Г.А. Двухфазные течения в элементах теплоэнергетического оборудования. Монография. М.: Энергоатомиздат, 1987. -328 с.

4. Скотникова М.А., Паршин А.М. Диаграмма распада и режим термической обработки двухфазных сплавов титана. // Металловедение и термическая обработка металлов. 1997. № 7. С. 31-37.

5. Скотникова М.А., Ланина А.А. Крылов Н.А., Иванов Е.К. Структурно-фазовые превращения в поверхностном слое лопатки паровой турбины при каплеударной эрозии // Проблемы ресурса и безопасной эксплуатации материалов, СПб: Изд-во СПБГУНиПТ, 2007. С. 102-107.

6. Скотникова М.А., Ушков С.С. Разработка научного принцип выбора окончательной термической обработки двухфазных горячедеформированных полуфабрикатов из сплавов титана // Прогрессивные материалы и технологии. / ЦНИИ КМ Прометей. - 1999. Вып. 3. С. 91-98.

7. Скотникова М.А., Чижик Т.А., Цыбулина И.Н. Ланина А.А., Крылов Н.А. Использование титановых сплавов в качестве материала лопаток паровых турбин. // Вопросы материаловедения. 2007. № 3 (51). C. $61-70$.

8. Скотникова М.А., Ланина А.А. Крылов Н.А. Хомченко Е.В. Особенности строения материала лопаток паровых турбин из титанового сплава ВТ6. // Сборник трудов: Проблемы материаловедения при проектировании, изготовлении и эксплуатации оборудования АЭС. СПб: Изд-во ФГУП ЦНИИ КМ "Прометей", 2010. С. 231-238.

9. Park Js., Margolin H. Role $\alpha$ - and $\beta$-phases in distribution of fatique crack to alloys Ti-Mn. // Metallurgical Transaction. 1984, Vol. 15A. № 1. P. 155-169.

10. Holl I., Khammond K. Distribution of alloing elements between the phases Titanium alloys during thermo-mechanical processing. // Proceedings Conference Titanium-77. Moscow, Russia, 1977. Vol. 1. P. 351.

11. Скотникова М.А., Чижик Т.А., Лисянский А.С., Симин О.Н., Цыбулина И.Н., Ланина А.А. Исследование рабочих лопаток турбин большой мощности с учетом структурно-фазовых превращений в металле штамповок из титанового сплава ВТ6 // Металлообработка. 2009. № 6(54). С. 12-21.

12. Гриднев В.Н., Ивасишин О.М., Ошкадеров С.П. Физические основы скоростного термоупрочнения титановых сплавов. Киев: Наукова думка, 1986. 256 с.

13. Ермолов М.И., Солонина О.П. Рентгеноструктурное исследование фазовых превращений при термообработке титанового сплава ВТ3-1// Физика металлов и металловедение.1967. Т. 23. № 1. C. 63-69. 


\section{СВЕДЕНИЯ ОБ АВТОРAX/AUTHORS}

KRYLOV Nikolai A. - Peter the Great St. Petersburg Polytechnic University.

29 Politechnicheskaya St., St. Petersburg, 195251, Russia.

E-mail: cryoff@rambler.ru

КРЫЛОВ Николай Александрович - кандидат технических наук ведущий научный сотрудник Санкт-Петербургского политехнического университета Петра Великого.

195251, Россия, г. Санкт-Петербург, Политехническая ул., 29.

E-mail: cryoff@rambler.ru

SKOTNIKOVA Margarita A. - Peter the Great St. Petersburg Polytechnic University.

29 Politechnicheskaya St., St. Petersburg, 195251, Russia.

E-mail: skotnikova@mail.ru

СКОТНИКОВА Маргарита Александровна - доктор технических наук заведующая кафедрой Санкт-Петербургского политехнического университета Петра Великого.

195251, Россия, г. Санкт-Петербург, Политехническая ул., 29.

E-mail: skotnikova@mail.ru

TSVETKOVA Galina V. - Peter the Great St. Petersburg Polytechnic University.

29 Politechnicheskaya St., St. Petersburg, 195251, Russia.

E-mail: tsvetkova_gv@mail.ru

ЦВЕТКОВА Галина Викторовна - кандидат технических наук доцент Санкт-Петербургского политехнического университета Петра Великого.

195251, Россия, г. Санкт-Петербург, Политехническая ул., 29.

E-mail: tsvetkova_gv@mail.ru

IVANOVA GalinaV. - Peter the Great St. Petersburg Polytechnic University.

29 Politechnicheskaya St., St. Petersburg, 195251, Russia.

E-mail: galura@yandex.ru

ИВАНОВА Галина Валерьевна - заведующая лабораторией Санкт-Петербургского политехнического университета Петра Великого.

195251, Россия, г. Санкт-Петербург, Политехническая ул., 29.

E-mail: galura@yandex.ru 